\title{
2006년 베트남 중간연도 원조공여국회의 개최 결과 보고
}

I . 핵심 요지

1. 회의 개요

- 표제회의(Informal Mid-Year Consultative Group Meeting for Vietnma)가 2006.6.9 10간 22개 주요 원조공여국, World Bank 및 $\mathrm{ADB}$ 등 13 개 국제기구 대표, 4 개 국제 NGO 대표 및 주재국 대표 등 약 400여명이 참석한 가운데 주재국 냐짱(Nha Trang)시 에서 개최됨.

- 베측은 Pham Gia Khiem 부총리, Vo Hong Phuc 기획투자부 장관 및 국회외교 위 부위원장, 중앙은행 부총재 및 무역 부 · 보건부 등 주재국 각부처 차관 등이 다수 참석(중간연도회의시 부총리의 참석 은 금번이 최초)

- 우리측은 베트남대사관 유연철 참사관, $\mathrm{KOICA}$ 베트남 사무소 김승범 사무소장 등
참석

\section{2. 주요 논의내용}

- 금번 회의는 (1) 베트남의 2006년 상반기 경 제 실적 점검 및 2006-2010 사회경제개발 계획(SEDP)의 성공적 이행을 위한 방안, (2) 원조의 조화 및 효율성 강화 방안 등에 대해 논의함.

-’06. 1-5월간 전년대비 수출 24\%, 산업생 산 $15.9 \%$, 외국인투자 $19.7 \%$ 증가

- 2010년까지 1인당 GDP 1,000불 이상, 수 출 매년 $22 \%$ 증가, 숙련노동인구 비율 $40 \%$, 고체폐기물의 $90 \%$ 처리 등 목표 수립 - 경제 · 사회 · 환경의 세 가지 축을 중심으 로한 지속 가능한 발전 강조

- 공여국들은 금번 회의시 주재국의 WTO 가 입 준비 및 부패 방지 등을 위한 제도적 · 법 률적 개혁 등의 제반 노력을 평가하고, 향후 
5년간 사회·경제개발계획의 목표 달성을 위한 커다란 장애요소가 부정부패임을 강조 하면서 이를 위해 governance system 의 구축 등 행정 개혁과 감시 기능의 강화가 필 수적임을 언급함.

- 주재국 공공구매법(4.1) 및 반부정부패법

(6.1) 발효, 투자법 · 기업법 및 환경보호법 발효 예정(7.1)

- 원조의 효율적 집행과 관련, 주재국 정부 는 $\mathrm{ODA}$ 관련 법률 개정 및 원조 전략 (ODA Framework)의 개선을 추진중이며 최근 교통부 고위 간부의 PMU(Project Management Unit) 18 프로젝트의 자금횡 령사건과 관련하여 현재 마련중인 PMU 규 정을 조속히 마무리할 예정임을 설명함.

- 2010년까지 ODA 지원규모는 11억불 정도 로 전망

- 효율적인 ODA 활용을 위해 분야별 우선 순위를 설정

- ODA 활용관련 농촌개발 및 빈곤감축분 야(21\%)와 교통 - 통신 및 도시개발분야 (33\%)는 증가 예상이나 에너지 · 산업분 야(15\%)는 여타 자원의 동원 가능성을 감안, 다소 감소 예상

- 공여국은 모든 레벨에서의 투명성과 책임감 을 높이는 것이 지속적인 성장을 위해 긴요 하다고 강조하면서 주재국 정부의 ODA 프 로젝트 관리체제의 합리화 노력을 평가함.

- 우리 대표단은 최근 우리나라의 ODA 정책방
향에 대해 설명하고, 선택과 집중의 원칙에 의해 베트남을 중점 지원 예정임을 발표함.

- 또한, 베트남 사회·경제개발계획의 세축 을 이루고 있는 환경분야에 대한 투자의 증가 필요성을 강조(경제분야에 대한 투자 비중은 약 $70 \%)$

- 반부패관련 행정개혁의 중요성과 조류독 감관련 우리 농림부의 전문가 초청사업 등 지원 계획 설명

- 차기 원조공여국 연례회의는 2006년 12 월 중 하노이에서 개최키로함.

\section{3. 관찰 및 평가}

- 금번 회의는 중간연도 원조공여국회의로서 는 최초로 주재국 부총리가 참석하고 기획투 자부장관을 비롯 다수의 각 부처 차관이 참 석한 바, 이는 금년도가 도이모이 20주년 및 $\mathrm{WTO}$ 가입, 사회경제개발계획의 출발이 되 는 중요한 해로서 금번회의의 중요성을 반영 한 것으로 사료됨.

- 특히, 금번회의시 부패방지를 위한 핵심적 요소로 행정개혁 및 제도적 개선의 필요성이 강조된 바, 우리로서도 반부정부패관련 경험 전수 등 관련 협력 사업의 추진을 모색하는 것이 시의 적절할 것으로 보임.

- 아울러, 베트남 정부의 투명성 확보를 위해 우리나라의 비교 우위 분야인 전자정부( $\mathrm{e}^{-}$ government) 관련 지원 방안을 검토하는 
것이 필요하다고 사료됨.

- 동건 관련 당지 $\mathrm{ADB}$ 소장은 $\mathrm{ADB}$ Trust Fund 내 한국측 기여 IT분야 기금을 활용 한 e-government 사업 추진의 가능성을 언급

\section{II. 의제별 논의 요지}

\section{Vo Hong Phuc 기획투자부 장관 개막 연설 요지}

- 지난 4 월 제 10 차 전당대회시 채택된 2006 2010 경제사회개발계획이 현재 국회에 제출 되어 조만간 승인될 예정임을 설명함.

- 사회경제개발계획의 실현을 위해 원조공여 국들의 적극적인 지원을 요청함.

\section{2006-10 사회경제개발계획(SEDP)}

\section{가. 베측 설명요지}

- 가뭄, 조류독감 등에도 불구하고 지속적으 로 경제가 성장하였으며, 양적 및 질적인 경제성장을 위해 민간부문 투자의 확대 계 획을 설명함.

- 지속가능한 개발을 통한 저개발국으로부터 의 탈피 및 국민의 생활환경의 개선을 2006-10까지의 목표로 설정하였으며, 사 회, 경제, 환경부문에서의 주요과제 및 목
표수치를 제시함.

- 2010년까지 1인당 GDP 1,000불 이상 등

\section{나. 주요 토론 내용}

- 지속적인 경제 성장을 위해서는 사회 정의 의 실현, 질적인 성장 및 책임감이 필요함 을 언급함.

- 빈부격차, 도시와 농촌지역간의 균형있 는 발전, 환경문제 해결방안을 포함한 질 적인 성장, 부패 방지를 위한 사회적 책 임감이 필요함을 제기

- 투자 허가 취득 등 외국인투자자본에 대한 규제완화를 요구함.

\section{3. 사회 경제 개발}

(경제 성장, HIV, 지속가능한 개발)

\section{가. 베측 설명 요지}

- HIV 분야에 대한 강력한 정책 및 법률 제 정을 추진하였으며, HIV에 대한 국가전략 의 효율적인 실행을 위해 국가 및 지방 정 부의 능력배양을 추진 중에 있음을 설명하 고 $\mathrm{HIV}$ 에 대한 공여국의 지속적인 관심과 지원을 요청함.

- 2010년까지 ODA지원규모가 11억불 될 것 으로 전망하며, 효율적인 $\mathrm{ODA}$ 동원 및 활 용(mobilization and utilization)을 위한 분야별 전략 및 우선순위를 소개함.

- 농촌 및 빈곤감축 분야와 교통 - 통신 및 
도시개발분야에 대한 지원 증대와 에너

지 · 산업화 부문에 지원은 감소

\section{나. 주요 토의 내용}

- 공여국들은 금번 $\mathrm{SEDP}$ 가 많은 이해관계자 들(Stakeholder)의 의견 수렴을 통해 마련 된 것에 대해 높게 평가하며, ODA의 질적인 향상을 위해 효율적인 ODA Management 가 필요함을 강조함.

- 아울러, 소수민족, 산간지역 주민에 대한 베 트남 정부의 관심을 요구하였으며, 균형 있 는 지역개발을 위해서는 Bottom up 방식으 로 지방정부의 계획이 반영되어 국가개발 계획이 수립되는 것이 필요함을 언급함.

- 또한 베트남 환경부문에 대한 지속적인 개발계획을 높게 평가하며, 지속적인 관 심과 세부계획(Action Plan) 실행 노력 을 요청

- 상업적인 성문제 해결 및 예방교육을 통해 $\mathrm{HIV}$ 문제를 해결하는 것이 필요하며, 교육 부, 재경부 등 타 부처와의 협력을 더욱 강 화할 것을 요청함.

\section{4. 제도 정비(부패 방지, WTO, 행정개혁 등)}

\section{가. 베측 설명 요지}

a 반부패법이 작년 11 월 국회에 의해 승인되 고 금년 6.1 부터 발효된 바, 베트남 정부는 투명하고 깨끗한 행정을 위해 지속적인 행
정개혁을 추진하고 있으며 또한 감사, 조사 기능을 강화할 계획임을 설명함.

- WTO가입 관련, 미국 등 주요 대상국과 원 활하게 협상되고 있음을 설명하면서, 향후 $\mathrm{WTO}$ 가입에 따른 충격에 대처하기 위해 은행개혁, 법적 제도 정비 등의 구체적인 계획을 설명함.

- 체계적인 공공 행정시스템 구축을 위해 행 정조직 개편, 제도 개선, 금융제도 개선, 공 무원 행정능력 강화 등을 추진하였음을 소 개하고, 행정서비스 능력 강화 등 5 개 프로 그램에 대한 차기 5 년간의 계획을 설명함.

\section{나. 주요 토의 내용}

- 반부패관련 투명성, 문서공개 등에 있어 많 은 진전이 있었음을 평가하면서 경제가 성 장하고 투자가 증가될수록 더욱 부패될 수 있음을 강조하면서, 장기적인 측면에서의 노력이 계속 필요함을 언급함.

- 반부패를 위해서는 투명성 확보, 정부의 책 임감, 공무원들의 급여에 대한 개선(pay reform) 및 언론 보장, 국회의 감시 기능 등이 필요함을 지적함.

- 덴마크, 스웨덴 등은 부패방지를 위해 법률 정비의 중요성에 대해서 지적하고 많은 부 분 상호 협력하고 있으며 이에 대한 지속적 인 지원을 약속함.

- WTO 협상에 대한 빠른 추진상황을 높게 평가하였으며, 베트남의 WTO 가입은 향 
후 경제에 긍정적인 영향을 미칠 것으로 전망하나, 이에 대한 여러 도전(challenge) 을 우려함.

\section{5. 분야별 추진 전략}

(재정, 교육, 농업, 교통, 기타)

\section{가. 베측 설명 요지}

\section{- 재정 분야}

: 투자 활성화, 경제 안정 등을 위해 지난 5 년간 끊임없이 재정 및 예산정책을 수정, 보완하였으며 지방정부 예산을 향후 1.9 배 확대할 예정이며, 투명한 재정운영을 위해 현대적 재정 관리 기법을 도입할 예정이라 고 설명함

\section{- 교육 분야}

: 베트남 국가개발전략에 있어 우선순위를 두고 있는 부분으로서, 인력자원의 질적 성장, 소수민족에 대한 교육 확대, 국제적 인 수준의 교육표준화를 추진할 예정이라 고 설명함.

- 농업 및 지역개발

: 조류독감, 가뭄 등의 악영향에도 불구하 고, 지난 5 년간 연평균 농업부문 성장률 $3.6 \%$ 를 시현하였으며, 고급기술 도입 및 시골지역 경제 발전을 통해 농업생산력 향 상을 도모할 계획임을 설명함.

\section{- 운 송}

: ODA 지원, 타 부처와의 협조 등을 통해
운송분야는 많은 진전이 있었음을 설명하 고 향후 도로, 항공, 철도 등의 인프라 건 설을 더욱 추진할 계획임을 강조함.

\section{나. 주요 토의 내용}

- 공여국은 사회경제개발계획이 여러 분야에 서 분야별 추진 전략을 수립하여, 프로그램 방식으로 추진되는 것에 적극 지지하며, 논 의된 상기 분야는 타부처와의 협력을 통해 종합적인 계획하에 추진되어야 할 것이라 고 강조함.

- HIV환자, 소수민족에 대한 교육문제에 대 한 해결방안이 더욱 구체적으로 마련되기 를 요청함

- HIV 환자에 대한 교육기회의 균등 제공 필요

- 소수민족에 대한 모국어 문제, 교육 커리 큐럼 부재 등을 지적

- 빈곤 감소를 위해서는 농촌경제를 더욱 활 성화시키고 도시지역의 숙련된 인력이 지 속적으로 배출될 수 있도록 관심이 필요함 을 지적함.

- 관광분야에 대한 투자 및 질적인 서비스 향상의 필요함을 지적

\section{6. 원조의 조화 및 효율성}

\section{가. 베측 설명 요지}

- 원조의 효율성 증대를 위해 ODA법률 17 조 
를 개정하고, 또한 기존에 수립된 원조전략 (ODA Framework)을 개선하고 있으며, 최 근 마련중에 있는 PMU 규정을 조속히 마 무리할 예정임을 설명함.

- 작년 3월 파리 고위급회담 후속조치로 수 립된 HCS (Hanoi Core Statment)에 대한 구체적인 실행을 위해 원조효과를 평가하 기 위한 Baseline Survey, ODA 데이터베 이스화 등을 추진하고 있음을 설명함.

\section{나. 주요 토의 내용}

- 공여국은 베측이 DAD(Development Assistance Database), Independent Monitoring 등을 원조효과 제고를 위한 후
속조치로 조속히 수립한 것을 평가하고, 이 에 대한 지속적인 실행을 요청함.

- HCS의 Indicator는 Bottom up 과 Top down 방식을 통해 수립되는 것이 필요하 며 특히 지방정부에서의 많은 노력과 관심 이 필요함을 지적함.

- 영국등의 대표단은 공여국간의 원조조화 및 부패방지를 위해 Cost Horns(비용 지 출에 대한 표준화)가 필요성을 제기함.

- 원조의 효율성 증대를 위한 제도적 기반강 화 등이 지속적으로 필요한 바, 특히 반부 패를 위한 정부의 강력한 리더쉽을 요청함.

[자료: 주베트남대사관] 
국제개발협력동향 2006년 제3호

\begin{tabular}{|c|c|}
\hline 발 & 2006년 10월 \\
\hline 편집 · 발행 & 한국국제협력단 정책연구실 \\
\hline 주 & 서울시 종로구 연건동 128 \\
\hline 전 & (02)740-5114 \\
\hline 팩 & (02)744-1092 \\
\hline 홈 페 이 주 & www.koica.go.kr \\
\hline$\hat{1}$ & 마스터-원 TEL.(02)2272-5002(代) \\
\hline
\end{tabular}

